\title{
PENGEMBANGAN BAHAN AJAR MATERI INDUKSI MATEMATIKA DAN TEORI BINOMIAL BERBASIS PEMBUKTIAN
}

\author{
Nurafni $^{1}$, Asih Miatun ${ }^{2}$, Hikmatul Khusna ${ }^{3}$, dan Hella Jusra ${ }^{4}$ \\ ${ }^{1}$ Universitas Muhammadiyah Prof. DR. HAMKA \\ nurafni@uhamka.ac.id \\ ${ }^{2}$ Universitas Muhammadiyah Prof. DR. HAMKA \\ asihmiatun@uhamka.ac.id \\ ${ }^{3}$ Universitas Muhammadiyah Prof. DR. HAMKA \\ hikmatulhusna@uhamka.ac.id \\ ${ }^{4}$ Universitas Muhammadiyah Prof. DR. HAMKA \\ hella.jusra@uhamka.ac.id
}

\begin{abstract}
ABSTRAK
Kemampuan mahasiswa dalam menyelesaikan pembuktian pada materi induksi matematika dan teori binomial masih kurang berdasarkan hasil ujian, sehingga disusunlah bahan ajar berbasis pembuktian. Penelitian ini menggunakan metode research and development dengan subjeknya adalah mahasiswa semester II Program Studi Pendidikan Matematika. Penelitian ini merupakan penelitian pengembangan yang terdiri dari 6 tahap. yaitu: Identifikasi Kebutuhan, Perencanaan, Pengembangan Produk Awal, Uji Coba Produk Awal, Revisi Produk, dan Uji Coba Lapangan sehingga menghasilkan bahan ajar. Dari hasil validasi dosen dan mahasiswa menunjukkan bahwa bahan ajar yang disusun valid dan layak digunakan dengan skor rata-rata sebesar 45 dan 45,93, sedangkan uji keefektifan bahan ajar yang dihitung menggunakan uji-t mendapatkan hasil bahwa $t_{\text {hitung }}>t_{\text {tabel }}, 5,83>2,11$, yang artinya terdapat peningkatan rata-rata nilai mahasiswa sebelum dan sesudah menggunakan bahan ajar. Dengan adanya peningkatan nilai tersebut menunjukkan bahwa bahan ajar yang disusun efektif digunakan.
\end{abstract}

Kata Kunci: pembuktian matematis, pengembangan bahan ajar, induksi matematika, teori binomial.

\begin{abstract}
Students' ability in solving argumentation in mathematical induction and binomial theory is still lacking based on the results of the exam, so that evidence-based teaching materials are prepared. This study uses design research methods with the subject from 2nd semester students of the Mathematics Education Study Program. This research is a development research consisting of 6 stages: Identification of needs, Planning, Initial product development, Initial product testing, Product revision, Field trials so as to produce teaching materials. The results of the lecturer and student validation show that the teaching materials are valid and feasible to use with an average score of 45 and 45,9333 . While the test of the effectiveness of teaching materials used using the $t$-test obtained results that $t_{\text {test }}>t_{\text {table }}$, $5.83>2.11$ which means there is an increase in the average value of students before and after using teaching materials. With the increase in value, it indicates that the instructional materials prepared are effectively used.
\end{abstract}


Keywords: mathematical proofing, development of teaching materials, mathematical induction, binomial theory.

Format Sitasi: Nurafni, Miatun, A., Khusna' H. \& Jusra, H. (2019). Pengembangan Bahan Ajar Materi Induksi Matematika dan Teori Binomial Berbasis Pembuktian. KALAMATIKA Jurnal Pendidikan Matematika, 4(1), 89-108.

Penyerahan Naskah: 28 Februari 2019 || Revisi: 2 Mei 2019 || Diterima: 2 Mei 2019

\section{PENDAHULUAN}

Pembuktian matematis merupakan suatu proses yang membutuhkan kemampuan matematika tingkat tinggi. Dalam proses pembuktian matematis, dibutuhkan penyusunan konjektur, model matematika, serta generalisasi untuk menghasilkan suatu pembuktian yang valid. NCTM (2000) menyatakan bahwa proses pembelajaran matematika membutuhkan kemampuan kognitif tingkat tinggi, menghasilkan argumentasi logis dan mempresentasikan pembuktian formal yang secara efektif menjelaskan penalaran mereka. Untuk itu diperlukan suatu metode dalam proses pembelajaran untuk mengembangkan proses bernalar mahasiswa pada suatu materi matematika.

Salah satu metode pengajaran di jurusan Pendidikan Matematika adalah metode pembuktian. Banyak mata kuliah di Jurusan Pendidikan Matematika yang pembelajarannya harus menggunakan metode pembuktian. Mahasiswa perlu melakukan langkah-langkah penyelesaian dari permasalahan yang diberikan dengan menerapkan pembuktian. Mahasiswa mengetahui bahwa notasi yang digunakan tidak dikenal atau tidak dapat dipahami atau mereka tidak memahami dari mana memulainya atau tidak mengetahui bagaimana memulai mengkonstruksi bukti. Bukti dan argumen merupakan dua hal penting dalam matematika dimana keduanya saling berhubungan. Vincent, Chick \& McCrae (2005) menyatakan bahwa argumen didefinisikan sebagai urutan pernyataan matematika yang bertujuan untuk meyakinkan, sedangkan argumentasi dapat dianggap sebagai sebuah proses di mana sebuah wacana matematika disampaikan dengan logis. Argumentasi membawa peran penting dalam membentuk suatu asumsi matematika yang mengarahkan pada suatu pembuktian.

Arnawa (2007) menyebutkan beberapa faktor yang mendukung kemampuan mengkonstruksi bukti dalam matematika. 
"Pertama, yaitu mampu mengidentifikasi apa yang menjadi fakta dalam pembuktian. Maksudnya adalah siswa mengetahuia apa saja yang menjadi modal awal untuk membuktikan dengan kaidah pembuktian yang logis matematis. Kedua, mampu mengidentifikasi apa yang menjadi kesimpulan dalam pembuktian matematika tersebut. Kesimpulan/conclusion ini sebagai langah terakhir dalam pembuktian yang merupakan hasil dari proses argumentasi. Ketiga, mampu menunjukkan aturan/warrant sebagai hal yang menjembatani fakta, argumen dan kesimpulan. Aturan dalam hal ini yaitu aksioma dan teorema matematika yang sah. Keempat, mampu membuat konjektur sebagai hipotesis dalam pembuktian. Konjektur juga diartikan sebagai membuat dugaan mengenai gagasan utama dalam pembuktian. Kelima, mampu mengevaluasi aturan-aturan penarikan kesimpulan dari proses argumentasi yang logis."

Bukti memang tidak selalu digunakan dalam matematika. Pembuktian dalam matematika berbeda pada pembuktian dalam bidang lainnya. Hoyles mengatakan bahwa pembuktian dalam matematika digunakan sebagai metode uji untuk pengetahuan yang terpercaya, yang berbeda dengan metode induktif yang digunakan pada bidang ilmu pengetahuan alam (Arnawa, 2007). Beberapa ilmuwan matematika mendefinisikan bukti matematika, Griffiths menyatakan bahwa bukti matematika merupakan suatu cara berpikir formal dan logis yang dimulai dengan aksioma dan bergerak maju melalui langkah-langkah logis sampai pada suatu kesimpulan (Juandi, 2008). Pembuktian suatu pernyataan matematika dalam sutu proses penalaran deduktif, yaitu proses yang berpangkal dari suatu himpunan pernyataan dan berakhir dengan suatu pernyataan yang disebut dengan kesimpulan. Ada beberapa materi matematika yang memerlukan metode pembuktian dalam mencari solusinya.

Induksi matematika merupakan salah satu materi yang memerlukan metode pembuktian dalam penyelesaiannya. Penggunaan induksi matematika dapat dilakukan untuk membuktikan suatu penyataan kebenaran untuk setiap bilangan bulat. Hine (2017) pun menyatakan bahwa induksi matematika adalah metode argumen bukti yang didasarkan pada rekursi dan digunakan untuk membuktikan dugaan yang mengklaim bahwa pernyataan tertentu benar untuk bilangan bulat dari beberapa variabel. Para siswa belajar bagaimana membuktikan macam-macam identitas dan ketidaksetaraan tertentu, serta sifat pembagian dengan bilangan asli (Ashkenazi, 2014). Hal ini sulit dilakukan menggunakan pembuktian secara langsung dengan cara melakukan pengecekan satu per satu kebenaran pada setiap bilangan bulat, sehingga dengan menggunakan penalaran dapat dibuktikan pernyataan kebenaran untuk setiap bilangan bulat dengan menggunakan induksi matematika. 
Prinsip pertama induksi matematika adalah if a set of positive integers has the property that, if it contains the integer $k$, then it also contains $k+1$, and if this set contains 1 then it must be the set of all positive integers (Raji, 2013).

Pembuktian matematis lain seperti pembuktian langsung, pembuktian deduktif, induktif, abduktif, dan lainnya juga sangat membantu dalam membuktikan kebenaran suatu pernyataan. Begitu pula pada teorema binomial yang berbicara seputar penerapan kombinasi. Membuktikan teorema binomial dapat menggunakan kombinasi maupun induksi matematika. Adapun bentuk umum dari teorema binomial, yaitu

$$
(1+a)^{n}=\left(\begin{array}{c}
n \\
0
\end{array}\right)+\left(\begin{array}{c}
n \\
1
\end{array}\right) a+\left(\begin{array}{c}
n \\
2
\end{array}\right) a^{2}+\left(\begin{array}{c}
n \\
3
\end{array}\right) a^{3}+\cdots+\left(\begin{array}{l}
n \\
k
\end{array}\right) a^{k}+\cdots+\left(\begin{array}{l}
n \\
n
\end{array}\right) a^{n},
$$

untuk setiap bilangan asli $n$.

Berdasarkan hasil penelitian yang dilakukan oleh Minggi, dkk (2016) tentang kemampuan mahasiswa dalam melakukan pembuktian, mahasiswa banyak mengalami kesulitan dalam melakukan pembuktian matematis, umumnya kesulitan yang dilakukan mahasiswa adalah sulit mengembangkan gagasan pembuktian. Kemudian hasil wawancara dari penelitian tersebut juga menunjukkan bahwa mahasiswa mengalami kesulitan dalam melakukan pembuktian. Hal ini menunjukkan kurangnya kemampuan mahasiswa dalam mengkontruksi bukti-bukti untuk mengembangkan strategi pembuktian menjadi suatu pembuktian matematika yang valid, sehingga diperlukan suatu bahan ajar yang dapat memfasilitasi mahasiswa membentuk keterampilan dalam menyusun dan mengembangkan strategi pembuktian matematika terutama dalam materi induksi matematika dan teorema binomial.

Bahan ajar merupakan faktor penting dalam kegiatan pembelajaran di kelas, Bahan ajar dirancang dan disusun secara sistematis yang memungkinkan mahasiswa dapat belajar secara mandiri, efektif, dan efisien. Sejalan dengan pendapat Koparan (2017) menggunakan material memiliki efek langsung pada realisasi tujuan pendidikan dalam proses pengajaran dan pembelajaran dan efek ini adalah salah satu alasan utama bagi guru untuk menggunakan material. Penggunaan bahan ajar dalam pembelajaran yang selama ini berlangsung adalah membelajarkan mahasiswa sesuai dengan buku teks yang digunakan oleh dosen. Menurut Suryadi (2013) sajian materi matematika dalam buku acuan, baik berupa uraian konsep, pembuktian, atau penyelesaian contoh masalah, sebenarnya merupakan sintesis dari suatu proses panjang yang berakhir pada proses dekontekstualisasi dan depersonalisasi, sehingga 
dalam proses pembelajaran yang dilakukan kurang melibatkan mahasiswa dalam mengkontruksi suatu konteks permasalahan. Upaya yang dilakukan untuk mengantisipasi permasalahan tersebut adalah dengan menyiapkan rancangan pembelajaran yang dapat mengkontruksi pikiran mahasiswa dalam melakukan pembuktian matematis melalui suatu refleksi proses pembelajaran yang telah dilakukan oleh dosen. Pemilihan dan penggunaan sumber belajar yang tepat dalam suatu aktivitas dan proses pembelajaran berperan penting dalam mengarahkan pengalaman belajar mahasiswa (Yudi, Ariani \& Ramadianti, 2017).

Pada dasarnya pengembangan bahan ajar harus selalu disesuaikan dengan kebutuhan mahasiswa dan kebutuhan kurikulum yang dipakai saat ini. Sejalan dengan pendapat Amri dan Ahmadi (2010) yang mengemukakan bahwa bahan ajar disusun dengan tujuan: (a) menyediakan bahan ajar yang sesuaidengan tuntutan kurikulum dengan mempertimbangkan kebutuhan siswa, yakni bahan ajar yang sesuai dengan karakteristik dan setting atau lingkungan sosial siswa; (b) membantu siswa dalam memperoleh alternatif bahan ajar disamping buku-buku teks yang terkadang sulit diperoleh; dan (c) memudahkan guru dalam melaksanakan pembelajaran. Materi yang disusun dalam bahan ajar ini adalah induksi matematika dan teorema binomial Secara garis besar materi induksi matematika dan teorema binomial berisi tentang pembuktian teorema-teorema. Induksi matematika merupakan salah satu argumentasi pembuktian suatu teorema atau pernyataan matematika yang semesta pembicaraannya himpunan bilangan bulat atau lebih khusus himpunan bilangan asli dan membuktikan teorema binomial menggunakan kombinasi maupun menggunakan induksi matematika.

Dengan melihat karakteristik materi induksi matematika dan teorema binomial dan kaitannya dengan pembuktian, maka pengembangan bahan ajar dengan menggunakan metode pembuktian diharapkan efektif dalam pembelajaran matematika. Berdasarkan penjelasan tersebut, perlunya menyusun bahan ajar pada materi induksi matematika dan teori binomial berbasis pembuktian agar mahasiswa dapat berpikir secara logis dan menggunakan penalarannya dalam menyelesaikan permasalahan matematika, serta mengetahuikevalidan, kepraktisan, dan keefektifan bahan ajar. Hal ini menunjukkan pembuktian sangat penting dalam matematika sebagai salah satu kemampuan yang perlu dimiliki oleh mahasiswa untuk mengembangkan kemampuan bernalarnya. Kurangnya kemampuan mahasiswa dalam mengkonstruksi bukti-bukti untuk mengembangkan strategi pembuktian menjadi suatu 
pembuktian matematika yang valid, sehingga diperlukan suatu bahan ajar yang dapat memfasilitasi mahasiswa dalam membentuk keterampilan untuk menyusun dan mengembangkan strategi pembuktian matematika.

\section{METODE PENELITIAN}

Metode yang akan digunakan dalam penelitian ini adalah metode penelitian research and design. Dalam hal ini, penelitian desain bertujuan untuk merumuskan, mengetahui, dan mengembangkan bahan ajar. Peneliti menggunakan desain penelitian pengembangan Borg dan Gall (Imamah, Lestari \& Gofur, 2016) yang telah dimodifikasi. Adapun prosedurnya sebagai berikut:

1. Identifikasi kebutuhan

Suatu proses yang sistematis untuk menentukan tujuan, mengidentifikasi ketidaksesuaian antara kenyataan dan kondisi yang diinginkan. Meliputi kajian pustaka, pengamatan atau observasi kelas dan persiapan laporan awal. Penelitian awal atau analisis kebutuhan sangat penting dilakukan guna memperoleh informasi awal untuk melakukan pengembangan.

\section{Perencanaan}

Perencanaan, yang mencakup merumuskan kemampuan, merumuskan tujuan khusus untuk menentukan urutan bahan, dan uji coba skala kecil (uji ahli atau uji coba pada skala kecil, atau expert judgement).

3. Pengembangan produk awal

Pengembangan format produk awal yang mencakup penyiapan bahan-bahan pembelajaran, handbook dan alat-alat evaluasi. Format pengembangan program yang dimaksud apakah berupa bahan cetak, urutan proses, atau prosedur yang dilengkapi dengan video.

4. Uji coba produk awal

Dilakukannya uji lapangan dalam setting atau situasi senyata mungkin dimana produk tersebut nantinya digunakan.

5. Revisi produk

Dikerjakan berdasarkan hasil uji coba lapangan. Hasil uji coba lapangan dengan melibatkan kelompok subjek lebih besar. Dimaksudkan untuk menentukan keberhasilan produk dalam pencapaian tujuan dan mengumpulkan informasi. 
6. Uji coba lapangan sehingga menghasilkan bahan ajar

Setelah dilaksanakan revisi produk, maka produk diujicoba pada subjek yang sesungguhnya guna didapat bahan ajar sesuai dengan permasalahan dan kebutuhan subjek penelitian.

Adapun pengambilan sampel dengan purposive sampling. Sedangkan, prosedur pada penelitian ini, yaitu sampel diberikan tes awal untuk mengetahuo sejauh mana mereka menguasai materi induksi matematika dan teori binomial, kemudian mahasiswa diberikan bahan ajar yang terdiri dari tugas-tugas yang harus diselesaikan melalui pembuktian matematika, sehingga mahasiswa dapat memahami dan menerapkan konsep dalam materi induksi matematika dan teori binomial, terakhir dilakukan wawancara dengan memberikan pertanyaan terurut yang diajukan kepada responden secara langsung.

\section{HASIL DAN PEMBAHASAN}

Hasil pengembangan dalam penelitian ini adalah berupa bahan ajar teori bilangan pada materi induksi matematika dan teorema binomial berbasis pendekatan. Bahan ajar yang dihasilkan berupa buku ajar. Langkah-langkah pengembangan bahan ajar untuk jenjang perguruan tinggi dengan prosedurnya sebagai berikut.

\section{Identifikasi Kebutuhan}

Analisis ini dilakukan untuk mengidentifikasi masalah dan fakta yang dijadikan dasar dalam pengembangan bahan ajar materi induksi matematis dan teorema binomial berbasis pembuktian. Masalah dan fakta diperoleh dengan melakukan obeservasi di kelas ketika mahasiswa semester dua mendapatkan mata kuliah teori bilangan. Peneliti sebelumnya pernah mengajar mata kuliah teori bilangan, berdasarkan hasil pengamatan peneliti, mahasiswa masih kesulitan ketika diminta untuk melakukan pembuktian pada soal induksi matematika dan teorema binomial. Padahal sebagian soal atau permasalahan pada materi ini berbasis pembuktian. Maka di sini peneliti merasa perlu untuk mengembangkan bahan ajar induksi matematika dan teorema binomial berbasis pembuktian yang sesuai dengan kebutuhan mahasiswa. Bahan ajar yang selama ini dipakai dirasa kurang memfasilitasi mahasiswa untuk meningkatkan kemapuan pembuktian terhadap masalah masalah induksi matematika dan teorema binomial. Bahan ajar harus disusun sesuai dengan kebutuhan kurikulum tanpa mengesampingkan kebutuhan mahasiswa terhadap bahan ajar yang mampu meningkatkan kemampuannya. Selain kondisi yang disebutkan di atas peneliti sebelumnya juga menjadi 
pengampu pada mata kuliah teori bilangan. Dari hasil penilaian terhadap mahasiswa khususnya pada materi induksi matematika dan teorema binomial menunjukkan bahwa nilai mahasiswa masih belum maksimal, dimungkinkan salah satu penyebabnya adalah bahanajar yang masih belum memfasilitasi kemampuan mahasiswa pada materi induksi matematika dan teorema binomial. Pada mata kuliah teori bilangan khususnya pada materi induksi matematika dan teorema binomial dibutuhkan kemampuan untuk bisa menggunakan metode pembuktian dalam penyelesaian masalah. Peneliti merasa bahwa bahan ajar yang selama ini digunakan belum berbasis pembuktian. Hal ini menjadi salah satu alasan bagi peneliti untuk menyusun bahan ajar induksi matematika dan teorema binomial yang berbasis pembuktian.

Beberapa kondisi yang telah disebutkan di atas, menjadikan dasar peneliti untuk melakukan penelitian dan pengembangan terhadap bahan ajar teori bilangan pada materi induksi matematika dan teorema binomial berbasis pembuktian.

\section{Perencanaan}

Pada tahap ini peneliti membuat rencana-rencana apa saja yang akan dibutuhkan dalam penelitian pengembangan bahan ajar ini. Selain bahan ajar induksi matematika dan teorema binomial ada beberapa instrumen yang harus ada dalam penelitian pengembangan. Di antaranya terdapat lembar validasi instrument dan pedoman wawancara. Berikut diuraiakan tahapan perencanaan dalam penelitian pengembangan ini.

\section{a. Pembuatan Bahan Ajar}

Pembuatan bahan ajar harus disesuaikan dengan tujuan awal yaitu bahan ajar induksi matematika dan teorema binomial berbasis pembuktian. Setiap sub materi yang disajikan dijelaskan dengan metode pembuktian sehingga mahasiswa nantinya diharapkan mampu menyelesaikan permasalahan yang ada dengan metode pembuktian. Selain itu disesuaikan juga dengan kurikulum yang ada. Bahan ajar ini memuat capaian pembelajaran dan indikator capaian pembelajaranyang sudah disesuaikan dengan kurikulum yang ada.

b. Pembuatan lembar validasi instrumen

Lembar validasi instrumen disusun berdasarkan analisis kebutuhan pada bahan ajar induksi matematika dan teorema binomial. Lembar instrument validasi disusun dengan mempertimbangkan aspek-aspek yang dapat mempengaruhi kualitas bahan ajar. Aspek tersebut diantaranya, aspek tampilan, penyajian materi, kecukupan, kedalaman, keluasan 
materi sesuai dengan kompetensi atau indikator pencapaian pembelajaran. Aspek-aspek yang ditampilkan pada lembar validasi instrument bisa dilihat pada tabel berikut:

\section{c. Soal Pretest dan Posttest}

Soal pretest dan posttest digunakan untuk mengukur seberapa efektif bahan ajar yang sudah dibuat ketika di uji coba lapangan. Pretest diberikan sebelum mahasiswa diberi perlakuan dengan pembelajan menggunakan bahan ajar induksi matematika dan teorema binomial berbasis pembuktian. Sedangkan posttest diberikan setelah perlakuan. Data dari pretest dan posttest ini diolah secara kuantitatif untuk melihat seberapa signifikan keefektifan bahan ajar induksi matematika dan teorema binomial yang sudah dibuat.

\section{d. Pedoman Wawancara}

Pedoman wawancara disusun berdasarkan hal-hal yang dinilai dari suatu bahan ajar. Pedoman wawancara ini nantinya akan diolah secara kualitatif sebagai feedback dari penilaian atau validasi instrument. Secara lebih lengkap lembar pedoman wawancara dapat dilihatdi lampiran

\section{e. Uji Coba Skala Terbatas}

Uji coba skala terbatas dilakukan untuk mengetahui kevalidan bahan ajar sebelum bahan ajar diujicobakan ke lapangan. Ujicoba skala terbatas ini melibatkan pakar/ahli dalam teori bilangan khususnya materi induksi matematika dan teorema binomial dan responden (mahasiswa) semester 3 yang sudah pernah mendapatkn mata kuliah teori bilangan. Hasil ujicoba skala terbatas ini nantinya akan di analisis dalam bentuk kualitatif maupun kuantitatif.

\section{Pengembangan Produk Awal}

Pengembangan produk awal pada penelitian ini adalah penyusunan bahan ajar teori bilangan pada materi induksi matematika dan teorema binomial. Bahan ajar disusun berbasis pembuktian dan disusun berdasarkan analisis kebutuhan mahasiswa dan disesuaikan dengan kurikulum yang ada (kompetensi dan indikator pencapaian kompetensi). Produk awal ini nantinya akan divalidasikan secara terbatas terlebih dahulu sebelum diujicobakan ke lapangan. Peneliti menganalisis berbagai sumber buku teori bilangan sebelumnya untuk membandingkan cakupan materi antara bahan ajar yang terdahulu dengan bahan ajar yang dibuat. Perbedaan bahan ajar terdahulu dan bahan ajar yang peneliti susun terletak pada metode pemecahan masalah. seperti yang sudah diketahui bahwa materi induksi matematika dan teorema binomial sebagian besar berbasis pada metode pembuktian. Peneliti menyusun bahan ajar ini dengan 
metode pembuktian dalam menyelesaikan masalah yang berkaitan dengan induksi matematika dan teorema binomial. Bahan ajar awal sebelum validasi secara lebih lengkap terdapat dilampiran.

\section{Uji Coba Produk Awal}

Uji coba awal merupakan validasi oleh ahli (expert Judgment) dan mahasiswa semester tiga yang sudah pernah mengikuti perkuliahan mata kuliah teori bilangan. Para ahli dan mahasiswa ini mengisi lembar validasi instrumen. Lembar validasi instrumen berisi indikator yang selanjutnya dibagimenjadi berbagai aspek penilian agar diketahui seberapa besar tingkat kevalidan bahan ajar yang sudah dibuat. Hasil pengisian lembar validasi instrumen akan dianalisis secara kualitatif dan kuantitatif.

\section{Revisi Produk}

Setelah melakukan ujicoba tahap awal (ujicoba terbatas) peneliti melakukan revisi terhadap bahan ajar teori bilangan pada materi induksi matematika dan teorema binomial. Revisi produk disesuaikan dengan penilaian atau validasi yang sudah dilakukan oleh expert judgement dan mahasiswa.

6. Uji Coba Lapangan

Tahap ini adalah tahap terakhir dalam pengembangan bahan ajar teori bilangan pada materi induksi matematika dan teorema binomial. Uji coba lapangan ini dilaksanakan pada subyek penelitian sesungguhnya. Subyek penelitian sesungguhnya yang dimaksud adalah mahasiswa yang akan diberi perlakuan pembelajaran materi induksi matematika dan teorema binomial menggunakan bahan ajar berbasis pembuktian yang sudah direvisi sebelumnya. Tahapan ujicoba lapangan, yaitu pretest, pembelajaran di kelas, dan posttest.

\section{Hasil Uji Coba Produk dan Pembahasan}

Uji coba produk dilakukan sebagai bagian dari usaha untuk mendapatkan produk yang memenuhi kriteria kevalidaan, keefektifan, dan kepraktisan. Uji coba produk merupakan penjelasan lebih lanjut dari tahap pengembangan (develop). Data yang dihasilkan dari uji coba berupa data tentang kevalidan, keefektifan, dan kepraktisan bahan ajar sebagaimana disajikan dalam Tabel 1.

Tabel 1. Tahap Uji Coba Produk dan Data yang Dihasilkan

\begin{tabular}{cccc}
\hline Tahap & Bentuk Uji Coba & \multicolumn{2}{c}{ Data yang Dihasilkan } \\
Kevalidan & Keefektifan \\
\hline 1. & Validasi ahli (dosen) & $\sqrt{ }$
\end{tabular}




$\begin{array}{ll}2 . & \begin{array}{l}\text { Uji coba terbatas } \\ \text { (mahasiswa) }\end{array} \\ \text { 3. } & \text { Uji coba lapangan }\end{array}$

$\sqrt{ }$

3. Uji coba lapangan

\section{Data Hasil Uji Coba Awal (Validasi Dosen)}

Uji coba awal pada penelitian ini dilaksanakan denganmelakukan validasi bahan ajar kepada ahli yaitu 3 orang dosen pendidikan matematika. Validasi dilakukan dengan memberikan instrumen validasi yang selanjutnya diisi oleh validator. Berikut akan disajikan secara lebih detail hasil dari uji coba produk yang meliputi kevalidan, keefektifan, dan kepraktisan bahan ajar teori bilangan pada materi induksi matematika dan teorema binomial, serta kategori konversi data.

Tabel 2. Kategori Konversi Data Kuantitatif ke Data Kualitatif

\begin{tabular}{cc}
\hline Interval Skor & Kategori \\
\hline$x>43,99$ & Sangat Baik \\
$36,66<x \leq 43,99$ & Baik \\
$22,33<x \leq 36,66$ & Cukup \\
$22,005<x \leq 29,33$ & Kurang \\
$x \leq 22,005$ & Sangat Kurang
\end{tabular}

Hasil validasi ahli (dosen) terhadap bahan ajar induksi matematika dan teorema binomial diperoleh rata-rata sebesar 45, berdasarkan tabel 2 dapat dilihat masuk ke dalam kategori sangat baik. Terdapat beberapa masukan dan saran perbaikan dari hasil validasi baik secaratertulis maupun secara lisan. Namun secara keseluruhan, bahan ajar yang dikembangkan "Layak Digunakan dengan Revisi". Bahan ajar yang direvisi selanjutnya diperbaiki. Bahan ajar sebelum dan revisi bisa dilihat pada lampiran.

Selain itu terdapat data hasil validasi dari setiap yang dinilai. Untuk lebih lengkapnya disajikan pada tabel berikut.

Tabel 3. Data Hasil Penilaian Setiap Aspek Ahli terhadap Bahan AjarInduksi Matematika dan Teorema Binomial

\begin{tabular}{llc}
\hline \multicolumn{1}{c}{ Aspek } & \multicolumn{1}{c}{ Indikator } & Rata-Rata Skor \\
\hline Tampilan & Kejelasan Teks & 4.666667 \\
& Kejelasan Gambar & 3 \\
& Gambar dapat menarik perhatian & 3.666667 \\
Penyajian Materi & Kesesuaian gambar dengan materi & 3.666667 \\
& Penyajian materi & 4.333333 \\
& Kemudahan memahami materi & 4 \\
& Ketepatan sistematika penyajian materi & 4.333333 \\
& Kejelasan kalimat & 4 \\
Kecukupan, Kedalaman, & Kejelasan symbol dan lambang \\
keluasan materi dengan & & Kejelasan istilah yang digunakan materi dengan kompetensi/indikator pembelajaran \\
kompetensi/ indikator & & 4.3333333 \\
pencapaian pembelajarann & & 4.666667 \\
\hline
\end{tabular}


Berdasarkan Tabel 3 terlihat bahwa rata-rata pada setiap aspek sudah lebih dari 4, sehingga dapat disimpulkan bahwa bahan ajar dalam kategori baik. Hanya beberapa aspek saja yang memberikan hasil cukup baik. Pada aspek kejelasan gambar, gambar dapat menarik perhatian dan kesesuaian gambar dengan materi mesihmemperoleh rata-rata sebesar 3. Baik saran secara tertulis maupun lisan validator menyebutkan bahwa bahan ajar yang disusun masih "minim" gambar tampilan dari bahan ajar yang disusun menjadi kurang menarik.

Ada 3 validator dosen pada tahap ini. Gambar 1 menampilkan saran dari validator untuk perbaikan bahan ajar materi induksi matematika dan teorema binomial.

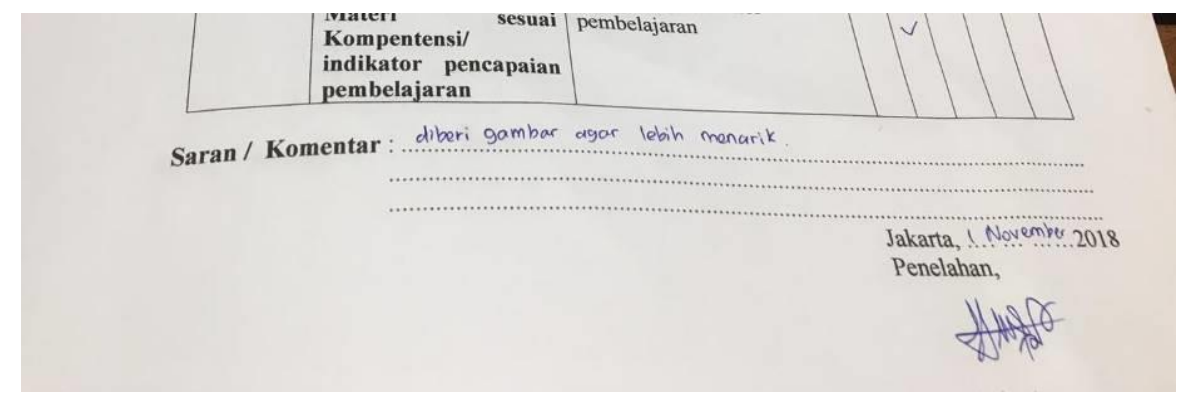

Gambar 1. Saran Tertulis Validator

Salah satu validator memberikan saran secara tertulis bahwa buku ajar yang dikembangkan masih perlu ditambahkan gambar agar lebih menarik, sedangkan dua validator yang lainnya tidak memberikan saran secara tertulis, dua validator yang lain menyebutkan bahwa bahan ajar yang disusun sudah cukup baik.

Selain penilaian, saran dan komentar yang tertulis pada lembar validasi instrumen, validator juga menuliskan saran pada bahan ajar secara langsung. Gambar 2 menampilkan perbaikan yang dituliskan oleh validator pada bahan ajar teori bilangan pada materi induksi matematika dan teorema binomial berbasis pembuktian.

\section{Teorema 1.2}

Jika $k$ dan $r$ bilangan-bilangan asli dengan $k>r$ maka $\left.\left(\begin{array}{c}k \\ r-1\end{array}\right)+\left(\begin{array}{l}k \\ r\end{array}\right)=\left(\begin{array}{c}k+1 \\ r\end{array}\right)\right)$

Soal Latihan

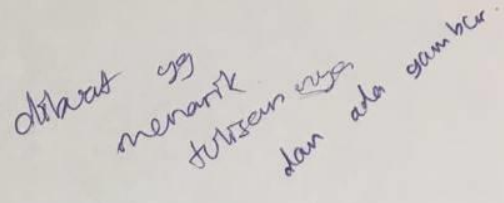

Buktikan pernyataan dibawah ini benar untuk setiap $n \in \mathbb{N}$ !

1. $1^{2}+2^{2}+3^{2}+\ldots+n^{2}=\frac{n(n+1)(2 n+1)}{6}$ 


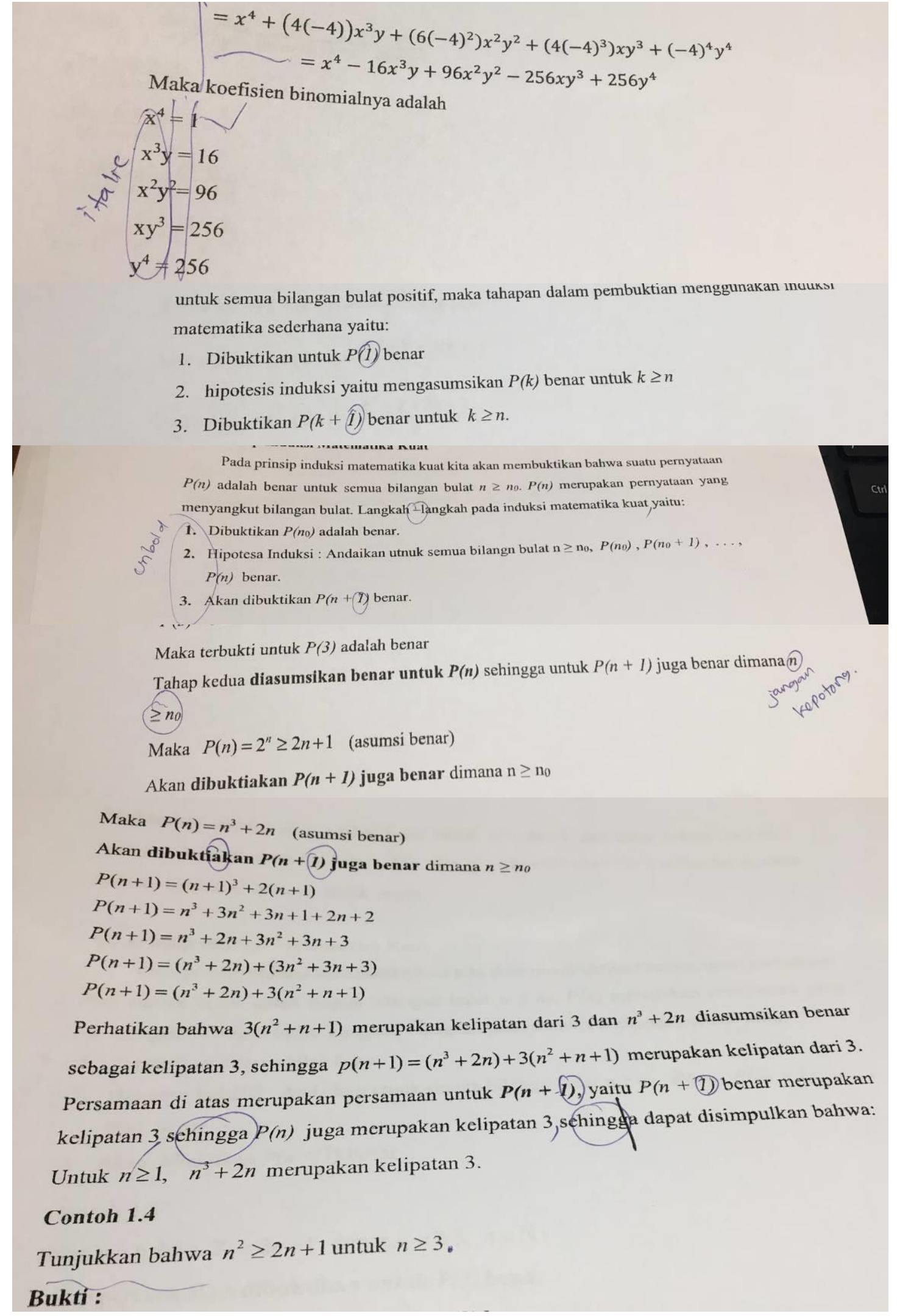

Gambar 2. Saran tertulis pada bahan ajar induksi matematika dan teorema binomial 
Gambar 2 menunjukkan bahwa saran yang ditulis oleh validator pada bahan ajar sebagian besar mengenai penulisan simbol, tanda, lambang, dan penulisan equation yang kurang tepat. Saran tertulis yang diberikan oleh validator akan menjadi acuan bagi peneliti untuk memperbaiki bahan ajar baik dari segi isi maupun segi tampilan.

\section{Uji Coba Terbatas (Mahasiswa)}

Hasil uji coba terbatas pada mahasiswa terhadap bahan ajar induksi matematika dan teorema binomial diperoleh rata-rata sebesar 45,9333, masuk ke dalam kategori sangat baik sesuai dengan kategori pada tabel 2. Rata-rata ini tidak berbeda jauh dengan rata-rata skor validasi oleh dosen atau ahli. Terdapat beberapa masukan dan saran perbaikan dari hasil validasi secara tertulis maupun secara lisan. Namun secara keseluruhan, bahan ajar yang dikembangkan "Layak Digunakan dengan Revisi". Bahan ajar yang direvisi selanjutnya diperbaiki. Bahan ajar sebelum dan revisi bisa dilihat pada lampiran.

Selain itu terdapat data hasil validasi dari setiap aspek yang dinilai. Untuk lebih lengkapnya disajikan pada tabel berikut.

Tabel 4. Data Hasil Penilaian Setiap Aspek Uji Coba Terbatas terhadap Bahan Ajar Induksi Matematika dan Teorema Binomial

\begin{tabular}{llc}
\hline \multicolumn{1}{c}{ Aspek } & \multicolumn{1}{c}{ Indikator } & $\begin{array}{c}\text { Rata-Rata } \\
\text { Skor }\end{array}$ \\
\hline Tampilan & Kejelasan Teks & 4.466667 \\
& Kejelasan Gambar & 4 \\
& Gambar dapat menarik perhatian & 3.2 \\
Penyajian Materi & Kesesuaian gambar dengan materi & 4.2 \\
& Penyajian materi & 4.666667 \\
& Kemudahan memahami materi & 4.266667 \\
& Ketepatan sistematika penyajian materi & 4.066667 \\
Kecukupan, Kedalaman, & 4.133333 \\
keluasan materi dengan & Kejelasan kalimat kompetensi/indikator pembelajaran & 4.2 \\
kompetensi/ indikator & & 4.066667 \\
pencapaian pembelajarann & & \\
\hline
\end{tabular}

Berdasarkan Tabel 4 terlihat bahwa rata-rata pada setiap aspek sudah lebih dari 4 , sehingga dapat disimpulkan bahwa bahan ajar dalam kategori baik. Hanya satu aspek saja yaitu aspek "gambar dapat menarik perhatian" yang memberikan hasil cukup baik. Berdasarkan hasil uji coba terbatas ini peneliti bisa memperbaiki bagian bahan ajar yang dinilai masih kurang. 
Ada 15 mahasiswa yang terlibat dalam uji coba terbatas ini. Selain memberikan validasi atau penilaian pada setiap aspek, mahasiswa juga memberikan saran secara tertulis untuk perbaikan bahan ajar. Berikut beberapa saran tertulis dari uji coba terbatas.

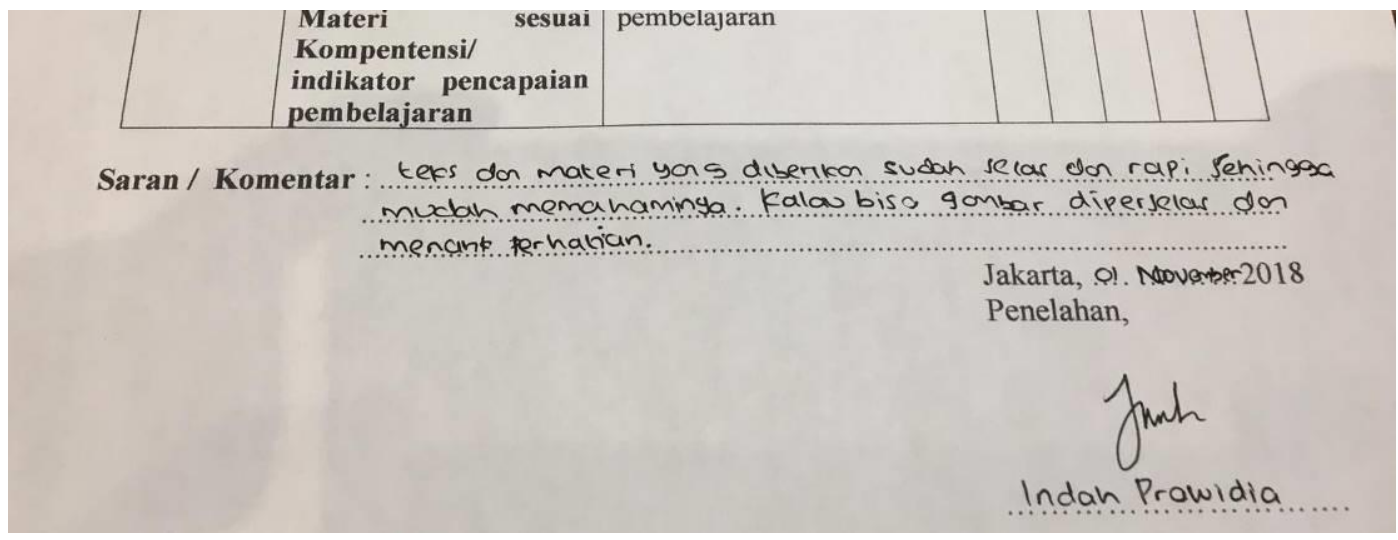

Gambar 3. Saran Uji Coba Terbatas 1

Gambar 3 menunjukkan salah satu saran dari responden memberikan komentar bahwa teks dan materi pada bahan ajar sudah jelas, serta penulisan pada bahan ajar juga sudah rapi. Responden menambahkan bahwa perlu ditambahkan gambar agar lebih menarik, agar bahan ajar tidak terlihat polos.

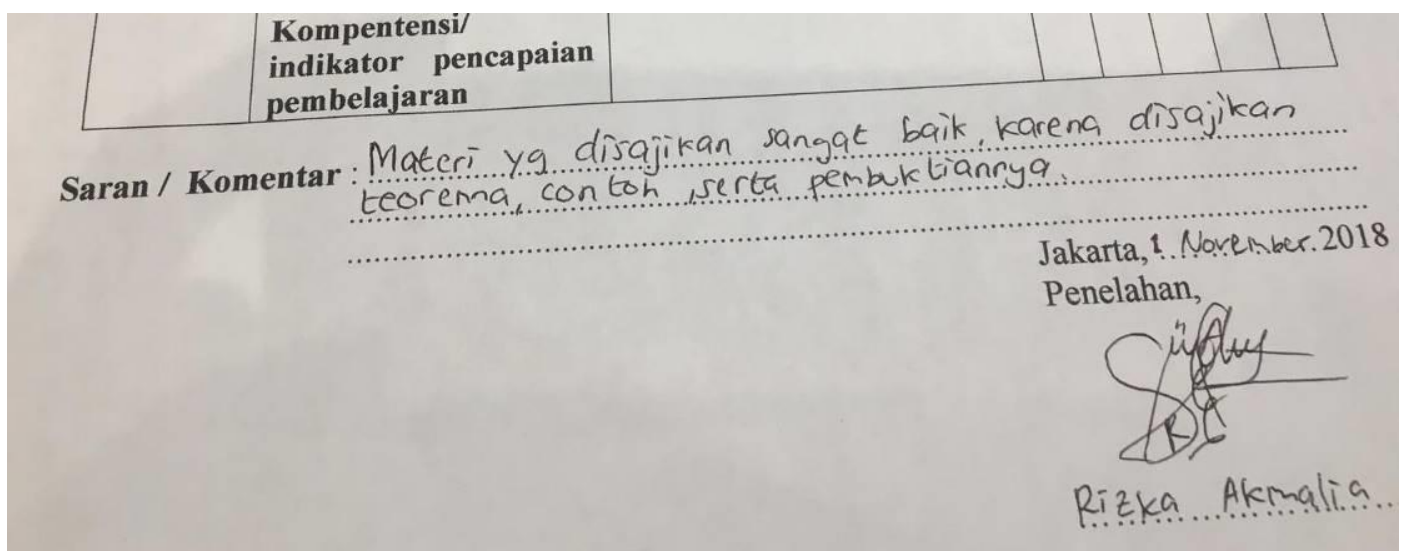

Gambar 4. Saran Uji Coba Terbatas 2

Gambar 4 menunjukkan bahwa bahan ajar yang sudah di buat sudah sangat baik. Sudah berbasis pembuktian sesuai dengan tujuan awal pembuatan bahan ajar induksi matematika dan teorema binomial. Materi pada bahan ajar inisudah disajikan lengkap dengan teorema contoh dan pembuktiannya. 


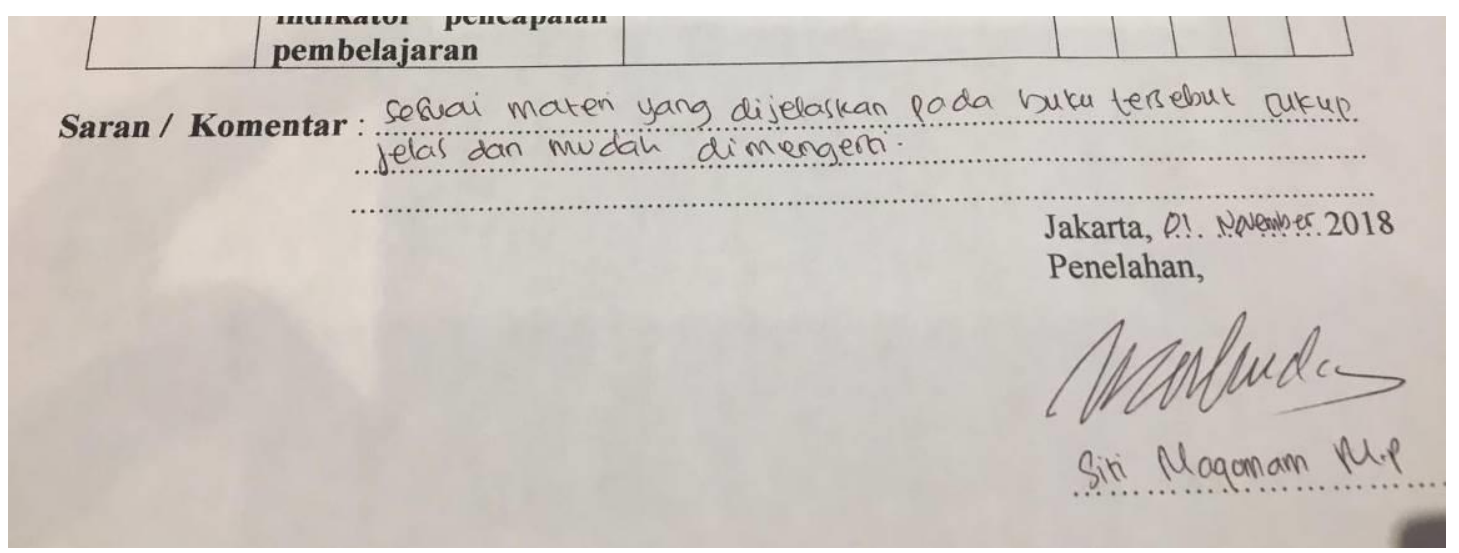

\section{Gambar 5. Saran Uji Coba Terbatas 3}

Gambar 5 menunjukkan bahwa bahan ajar yangsudah dibuat cukup jelas mudah dimengerti oleh mahasiswa. Sesuai dengan judul penelitian ini, bahwa bahan ajar yang dibuat berbasis pembuktian. Tujuan peneliti membuat bahan ajar berbasis pembuktian karena pada materi induksi matematika dan teorema binomial, sebagian materinya dikerjakan dengan metode pembuktian.

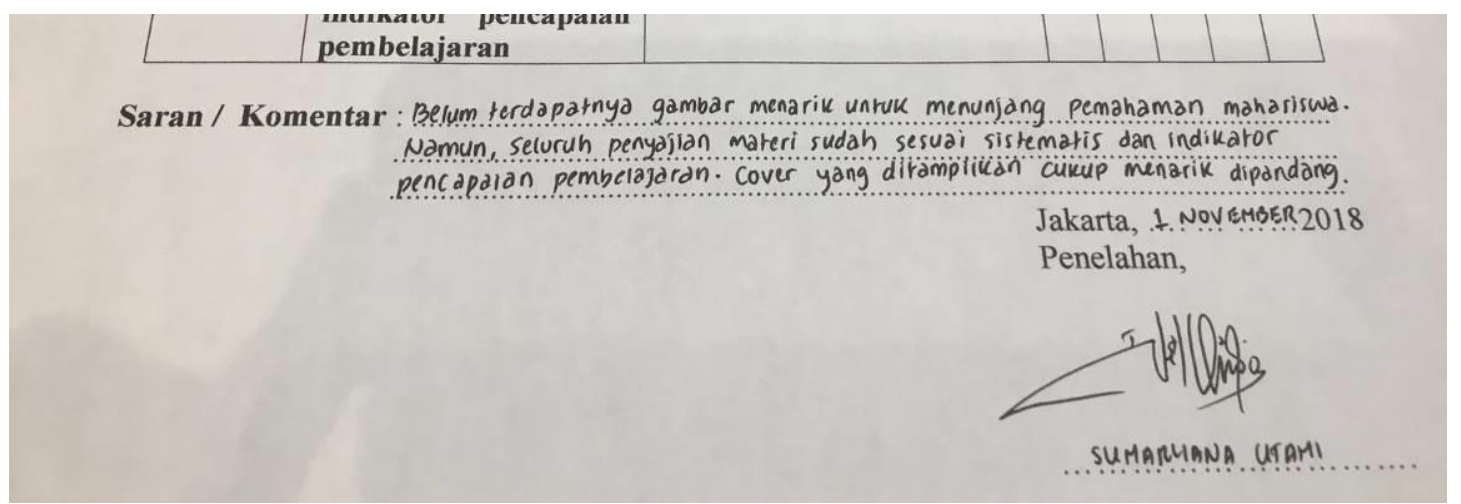

Gambar 6. Saran Uji Coba Terbatas 4

Gambar 6 menunjukkan bahwa bahan ajar yang dibuat masih kurang gambar sehingga terlihat kurang menarik. Selain itu responden memberikan komentar bahwa gambar yang menarik dapat menunjang pemahaman mahasiswa. Penyajian materi sudah sistematis dan sesuai dengan kompetensi dan indikator pencapaian kompetensi. Saran ini menjadi salah satu pertimbangan bagi peneliti untuk memperbaiki bahan ajar supaya secara visual bahan ajar yang ditampilkan menjadi lebih menarik. 


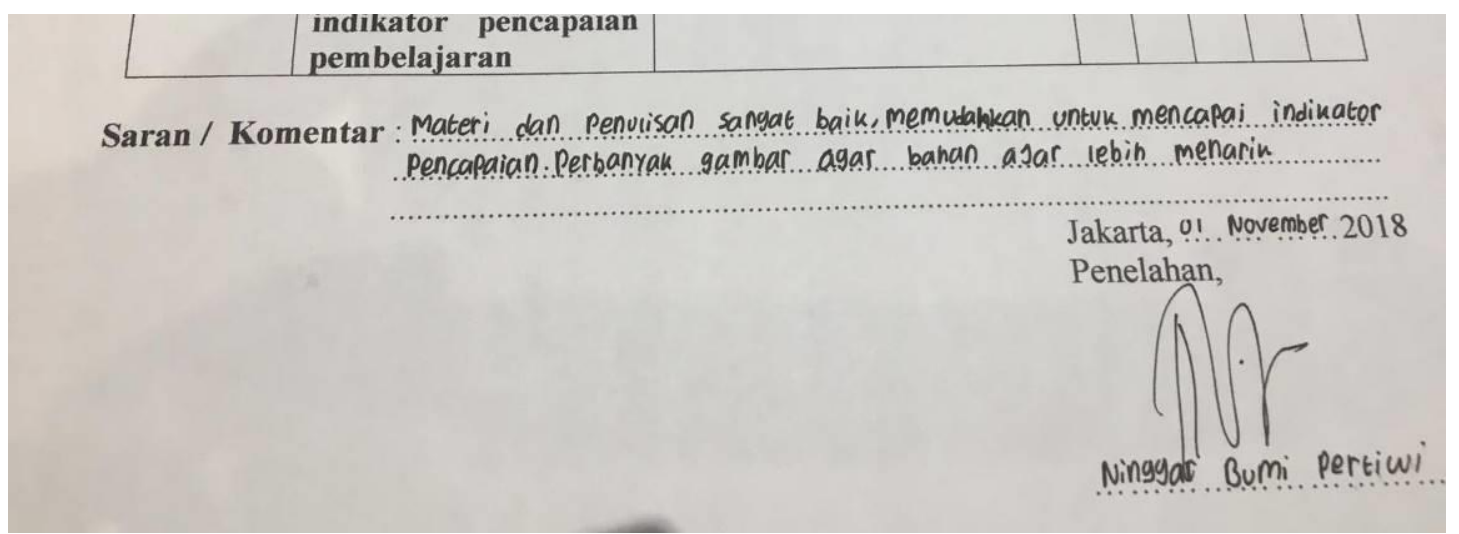

Gambar 7. Saran Uji Coba Terbatas 5

Gambar 7 menunjukkan bahwa bahan ajar yang dibuat sudah baik dan sesuai dengan indikator pencapaian kompetensi. Seperti saran sebelumnya, bahan ajar ini juga masih minim gambar sehingga masih perlu diperbaiki lagi sehingga tampilannya menjadi lebih menarik.

Saran-saran di atas merupakan beberapa saran atau komentar yang diberikan secara tertulis untuk perbaikan bahan ajar induksi matematika dan teorema binomial berbasis pembuktian. Sebagian mahasiswa memberikan saran untuk memberikan gambar pada bahan ajar, sehingga bahan ajar akan menjadi lebih menarik. Sebagian lagi memberikan komentar bahwa bahan ajar yang disusun sudah cukup baik karena sudah memenuhi kriteria bahan ajar berbasis pembuktian.

\section{Uji Coba Lapangan}

Uji coba lapangan ini untuk mengetahui seberapa efektif bahan ajar teori bilangan pada materi induksi matematika dan teorema binomial. Bahan ajar yang efektif bisa digunakan untuk pembelajaran materi induksi matematika dan teorema binomial. Oleh karena itu, bahan ajar harus di uji keefektifannya terlebih dahulu dengan tahap-tahap uji coba lapangan adalah menghitung hasil pretest, posttest, dan analisis kefektifan bahan ajar.

Setelah bahan ajar direvisi sesuai saran dan masukan validator dan mahasiswa, bahan ajar digunakan dalam kegiatan pembelajaran. Selama proses pembelajaran di kelas mahasiswa menggunakan bahan ajar berbasis pembuktian yang sudah direvisi. Pada pembelajaran ini mahasiswa diwajibkan menggunakan bahan ajar yang sudah disusun dan mengerjakan soal latihan yang terdapat pada bahan ajar. Ketika melaksanakan pembelajaran di kelas mahasiswa terlihat lebih antusias menggunakan bahan ajar yang berbasis pembuktian. Bahan ajar yang sudah disusun peneliti diharapkan dapat memfasilitasi mahasiswa untuk meningkatkan 
kemampuan penyelesaian masalah menggunakan metode pembuktian berdasarkan jawaban mahasiswa. Berikut hasil dari perhitungan efektifitas dengan uji-t:

Tabel 5. Hasil Uji Efektifitas Bahan Ajar

\begin{tabular}{lcccc}
\hline Tes & $\mathrm{n}$ & Rata-rata & $\mathrm{t}_{\text {hitung }}$ & $\mathrm{t}_{\text {tabel }}$ \\
\hline Pretest & 18 & 53 & 5,83 & 2,11 \\
Posttest & 18 & 79,44 & & \\
\hline
\end{tabular}

Berdasarkan Tabel 5 terdapat peningkatan rata-rata nilai mahasiswa sebelum dan sesudah menggunakan bahan ajar induksi matematika dan teorema binomial dengan rata-rata dari selisih pretest dan posttest sebesar 26,44 dan hasil pengujian dengan uji-t sebesar 5,83.

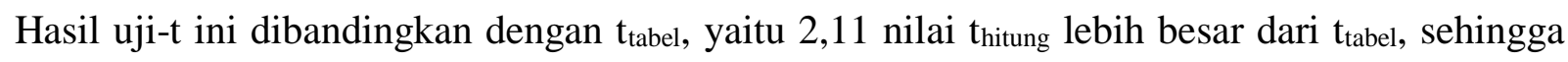
terjadi peningkatan rata-rata nilai mahasiswa sebelum dan sesudah menggunakan bahan ajar. Dapat disimpulkan bahwa bahan ajar yang disusun efektif digunakan untuk proses belajar mengajar. Hasil uji keefektifan ini sejalan dengan uji validasi yang dilakukan sebelumnya, yang memberikan hasil bahwa bahan ajar teorema binomial dan induksi matematika sudah valid dan layak untuk digunakan. Hasil pengembangan bahan ajar ini selanjutnya akan digunakan untuk perkuliahan mata kuliah teori bilangan pada materi induksi matematika dan teorema binomial. Selain itu, hasil nilai pretest dan posttest mahasiswa terlihat bahwa semua nilai mahasiswa meningkat secara signifikan, selain dilihat berdasarkan selisih nilai pretest dan posttet, peningkatan secara signifikan juga dibuktikan dengan menggunakan uji-t. Peningkatan nilai mahasiswa menunjukkan bahwa bahan ajar yang sudah disusun memberikan pengaruh terhadap proses belajar mengajar di kelas. Penggunaan bahan ajar induksi matematika dan teorema binomial berbasis pembuktian dapat meningkatkan nilai mahasiswa.

\section{KESIMPULAN}

Berdasarkan hasil analisis data dan pembahasan diperoleh simpulan bahwa bahan ajar yang dihasilkan dari penelitian dan pengembangan ini berupa bahan ajar teori bilangan pada materi induksi matematika dan teorema binomial berbasis pembuktian, bahan ajar termasuk ke dalam kategori sangat baik, sehingga memenuhi kriteria kevalidan bahan ajar. Bahan ajar yang dihasilkan dari penelitian ini, penilaian dari validator dosen dan mahasiswa bahan ajar termasuk dalam kategori "sangat baik". Selain itu, produk yang dihasilkan dalam penelitian dan pengembangan ini telah memenuhi kriteria efektif, yaitu nilai mahasiswa mengalami peningkatan secara signifikan. 


\section{REKOMENDASI}

Adapun perlunya dilakukan penelitian lanjutan terhadap bahan ajar yang dikembangkan ini untuk mengetahui keefektifan produk dalam peningkatan konteks yang lebih luas, serta bahan ajar ini dapat dikembangkan pada lingkup yang lebih luas.

\section{REFERENSI}

Amri, S. \& Ahmadi, K. I. (2010). Proses Pembelajaran Kreatif dan Inovatif di dalam Kelas. Jakarta: Prestasi Pustaka Karya.

Arnawa, I. M. (2007). Mengembangkan Kemampuan Mahasiswa dalam Memvalidasi Bukti pada Aljabar Abstrak melalui Pembelajaran Berdasarkan Teori APOS. Jurnal Matematika dan Sains, 14(2), 64.

Ashkenazi, Y. \& Itzkovitch, E. (2014). Proof by Mathematical Induction. International Journal of Innovative and Reasearch in Educational Science, 1(3), 186 - 190.

Hine, G. (2017). Proof by Mathematical Induction: Professional Practice for Secondary Teachers. Paper presented at the Australian Association of Mathematics Teachers Biennial Conference, Australian Capital Territory, Canberra.

Imamah, E. Q., Lestari, U. \& Gofur, A. (2016). Pengembangan Booklet dari Penelitian Pengaruh Tahu Berformalin terhadap Histopatologi Hati Mencit Jantan Galur Balb/C untuk Masyaraka Kota Kediri. Jurnal Pendidikan Biologi Indonesia, 2(2), 102-108.

Juandi, D. (2008). Pembuktian, Penalaran, dan Komunikasi Matematika. Bandung: FMIPAUPI.

Koparan, T. (2017). Analysis of Teaching Materials Developed by Prospective Mathematics Teachers and Their Views on Material Development. Malaysian Online Journal of Educational Technology, 5(4).

NCTM. (2000). Principles and Standar for School Mathematics. Reston, VA: The National Council of Teachers of Mathematics, Inc. 
Raji, W. (2013). An Introductory Course in Elementary Number Theory. The Saylor Foundation.

Suryadi, D. (2013). Didactical design research (DDR) dalam pengembangan pembelajaran matematika. In Prosiding Seminar Nasional Matematika dan Pendidikan Matematika (pp. 3-12).

Vincent, J., Chick, H., \& McCrae, B. (2005). Argumentation Profile Charts as Tools for Analysing Students'argumentations. International Group for the Psychology of Mathematics Education, 281.

Yudi, M., Ariani, N. M., \& Ramadianti, W. (2017). Desain Bahan Ajar Mata Kuliah Aljabar Linear untuk Mengembangkan Kemampuan Berfikir Kreatif Matematis. KALAMATIKA Jurnal Pendidikan Matematika, 2(1), 1-14. 